\title{
Joseph Moyo*
}

\author{
Department of Applied Languages \\ Tshwane University of Technology, South Africa \\ MoyoJ@tut.ac.za
}

\section{Charles C. Mann}

Department of Applied Languages

Tshwane University of Technology, South Africa

MannC@tut.ac.za

\section{FACE VALIDITY IN ESP: A QUANTITATIVE STUDENT VALIDATION OF AN ENGINEERING ESP APPROACH}

\section{Abstract}

This study sought to test Engineering students' responses to an English for Specific Purposes (ESP) module at a South African university, since Engineering students typically viewed ESP modules negatively. A self-designed questionnaire with two 15item and three 9-item Likert-type scales were used to gather quantitative data in a predominantly survey research design. The questionnaire was administered on Engineering students $(\mathrm{N}=226)$ at the end of the semester after they had attended the ESP module. The questionnaire data were processed with SPSS, and analysed with means, Chi Square, ANOVA, and Games Howell and Scheffe post hoc tests. The responses were evaluated as negative or positive, on the basis of consistency with ESP principles, and relevant education theory. The findings revealed that two-thirds (10) of the item means were indicative of a high degree of face validity on relaxed criteria, while a third (5) signified a low degree of face validity. On much stricter criteria, the ratio changed to 58:42, still in favour of a high degree of face validity. In spite of the high degree of face validity (relevance and usefulness), it appeared as if the respondents still had lingering doubts about the inclusion of English Communication Skills modules in Engineering learning programmes.

\section{Key words}

ESP, Engineering, curriculum design, face validity, attitude, motivation.

\footnotetext{
* Corresponding address: Joseph Moyo, Department of Applied Languages, Tshwane University of Technology, Pretoria West, Private Bag X680, Pretoria 0001, South Africa.
} 


\section{Sažetak}

Cilj ovog istraživanja bio je da ispita stavove studenata tehničkih nauka sa jednog južnoafričkog univerziteta prema nastavnom kursu engleskog jezika struke, s obzirom na to da budući inženjeri uglavnom imaju negativne stavove prema ovakvim kursevima. U tu svrhu primenjeno je kvantitativno istraživanje anketnog tipa putem upitnika koji je konstruisan za potrebe istraživanja i koji su činile dve skale sa po 15 stavki Likertovog tipa i tri skale sa po 9 stavki Likertovog tipa. Ukupno $\mathrm{N}=226$ studenata tehničkih nauka popunilo je upitnik na kraju semestra tokom kojeg su pohađali kurs iz engleskog jezika struke. Za obradu podataka prikupljenih putem upitnika korišćen je SPSS, dok su primenjeni testovi uključili srednju vrednost, hi-kvadrat, ANOVU i Games Howell i Scheffe post-hok testove. Odgovori su ocenjeni kao pozitivni, odnosno negativni na osnovu podudarnosti sa principima engleskog jezika struke, kao i sa relevantnim pedagoškim teorijskim principima. Rezultati pokazuju da dve trećine (10) srednjih vrednosti stavki upućuju na visok stepen spoljne validnosti kada su primenjeni blaži kriterijumi, dok trećina (5) upućuje na nizak nivo spoljne validnosti. Kada su primenjeni stroži kriterijumi, rezultati su pokazali da je taj odnos 58:42, i dalje u korist visokog nivoa spoljne validnosti. Uprkos ustanovljenom visokom nivou spoljne validnosti (za varijable relevantnosti i korisnosti), čini se da ispitanici i dalje izražavaju sumnje po pitanju uključivanja kurseva iz komunikacionih veština na engleskom jeziku u kurikulume studija tehničkih nauka.

\section{Ključne reči}

engleski jezik struke, tehničke nauke, osmišljavanje kurikuluma, spoljna validnost, stavovi, motivacija.

\section{INTRODUCTION}

Many ESP-type modules in South Africa started out as academic support programmes introduced in South African traditional universities to address the underachievement of historically disadvantaged students at historically white universities. The failure of these programmes, which consisted of pull-out, noncredit-bearing modules in English and study skills (Evans, 1995: 59), led to their replacement with compulsory, credit-bearing modules that employ the English for Specific Purposes (ESP) approach (Kilfoil, 1998: 46). At the same time, former technikons (now universities of technology) have been offering Business Communication modules as an integral part of their qualifications since 1981 (Vongo, 2005: 42). Meanwhile, ESP courses have themselves evolved from being 
purely about language to also focussing on developing effective communication skills (Barnard \& Zemach, 2003: 310). Most university learning programmes, including Engineering ones, now legally have to include an ESP-type module as a service module, which is an ancillary module taught in support of a major (Sulcas \& English, 2010: 219). In spite of, or, perhaps, because of, their compulsory status, ESP modules are viewed in certain settings with suspicion by students and subject specialists. For example, in a course design report on a University of South Africa (UNISA) science ESP module, Kilfoil (1998: 47-48) found that both the students who performed well and badly in English regarded it as an unnecessary burden, while the subject specialists viewed it as ineffective. Subject specialists, in particular, believe that soft skills, such as communication, take up the valuable time that students could be using to acquire the technical skills of their specialist subjects (Grant, 2003 as cited in Sulcas \& English, 2010: 219). A study by Vongo (2005: 58), at the former Technikon Witwatersrand (now part of the University of Johannesburg), found that students questionably regarded the Business Communication module as a repetition of high school work, and, thus, a waste of time.

This research investigated the apparent disaffection of Engineering students toward an ESP-type module labelled "Engineering Communication" (EC) at a university in South Africa's Gauteng Province. Although this investigation could be classified as a student evaluation of an ESP-type module, it went farther, and examined student views on the main tenets of the ESP approach. The following research questions were posed:

- Do students' attitudes toward the Engineering ESP module at the chosen university reflect a low or high degree of face validity? In other words, does the selected ESP module generate a desirable high degree of face validity for the students?

- Are the learners motivated, as predicted they would be by ESP theory, if, indeed, the ESP modules have high face validity?

- Which of the measured face validity variables represented a low face validity threat?

It was expected that the Engineering students would attribute a low degree of face validity, as defined in the study, by either agreeing or disagreeing with the selected face validity Likert-scale and Likert-type scale items if attitudes reflect face validity. This would be the case if the mean, or the mean of means, was less than 3.50. In other words, the Null Hypothesis would be rejected if the means, or the mean of means, was less than 3.50, and fail to be rejected if it was greater than or equal to 3.50. Failure to reject the Null Hypothesis would suggest the existence of evidence in support of the Alternative Hypothesis that there was a high degree of face validity. The following is the hypothesis in notation form, in which the symbols $\mathrm{H} 0$, $\mathrm{Ha}$ and $\mu$ mean Null Hypothesis, Alternative Hypothesis and Population Mean, respectively: 
H0: $\mu<3.5$

Ha: $\mu \geq 3.5$

The confidence level would be $95 \%(0.95)$, and the confidence interval, $5 \%(0.05)$.

\section{REVIEW OF THE PRINCIPAL THEORETICAL CONCEPTS AND FRAMEWORK}

In educational theory and praxis, which is the context of this study, achieving validity on some criterion, value, or principle - which, in ESP, is relevance - is the goal of any curriculum development. In accountable and relevant-education systems, modules or courses are designed through curriculum development or design processes by course design professionals with the goal of securing the endorsement of the stakeholders, specifically the learner end-users. Curriculum development includes design component, and an evaluation component, by which feedback - generally referred to as face validity (if it comes from learners), is obtained from the learners, as to the impact of the module as an educational design. The feedback, which is typically the result of a student evaluation, is usually about aspects of the implementation of the learning experiences planned in the development phase, including the teaching, teacher, and syllabus, and are hardly about the much more profound issues of the teaching approach, philosophy, or ideology, and its operationalisation, which could, nonetheless, be to blame, if learners were disaffected by, or indifferent to, the content and delivery of modules.

\subsection{Face validity as a consequence of validity}

Nevo (1985: 288, 290), who defines face validity as the feelings, attitudes, and opinions of testees, raters, or examinees toward a test, also proposes that face validity be understood through the prism of validity, i.e. the hypernymic concept, which suggests that face validity is the raters' interpretation of what was intended as validity by the course designer, except that the rater may be limited by knowledge and experience, thereby necessitating the labelling of the validation as face validity, instead of validity-proper. Nevo's suggestion necessitates a review of validity concepts. Two conventional validity perspectives exist, particularly in psychometrics (psychological and educational assessment), the field that typically develops nomothetic standards of validity: the traditional view, also called the trinitarian doctrine, which holds that validity is a multidimensional concept made up of three types of validity: construct, criterion-related, and content validity; and, the modern view, also called the unitarian view, which sees validity as a unitary concept, consisting of six aspects of construct validity: the content, consequential, substantive, structural, generalisability, and external aspects. The traditional view 
could be divided into two: the conservative one, which is hostile to face validity on the premise of the distinction that it makes between face validity (perceived validity characterised as fake) and validity (real or actual validity) (Anastasi, 1988: 144); and, the moderate view, which, typified by Nevo's concept (1985), acknowledges face validity as a legitimate fourth validity type. The unitarian validity concept, pioneered by Samuel Messick since the late 1970s, has replaced the traditional view as an orthodoxy, although the latter is still applied in practice. Messick's validity concept, which, by the accounts of Baghaei and Yazdi (2016: 169-170), and Colliver, Conlee, and Verhulst (2012: 367-369), has also recently been challenged by Borsboom, Mellenbergh, and van Heerden (2004), essentially re-defines validity, renames the subdivisions of validity from types into aspects, extends the number of these subdimensions from three to six, and argues that they are a single concept called construct validity. Messick (1989 as cited in Messick, 1998: 3) re-defines validity as "an integrated overall evaluative judgment of the degree to which empirical evidence and theoretical rationales support the adequacy and appropriateness of interpretations and actions on the basis of test scores or other modes of assessment". Although Messick hardly refers to face validity by name in his work, which is understandable, given the hostility towards the concept in his field, he seems to incorporate the traditional face validity concerns into his integrated validity concept under the consequential aspect. Whereas the concept, validity, was developed and used mainly in psychometrics (the science of testing), its relevance extends beyond tests as educational designs to more educational designs, such as needs analyses, syllabuses, modules, learning programmes, educational systems, etc. (Weidemann, 2011: 10).

The definition of face validity as attitudes implies that efforts, such as those in some ESP approaches, to objectivise face validity by defining it as objective resemblance to, or correspondence with, the targeted entities in the real world (materials, tasks, and experiences), giving face validity something of the meaning of authenticity, could be considered insufficient. As Nevo's (1985: 289) operational definition makes clear, face validity is considered measured when there is a degree of perception - real or virtual - of relevance, usefulness, or suitability, on the one hand, or irrelevance, or unsuitability, on the other, in respect of the object being evaluated. In this sense, face validity appears to be much broader than just perceived realness or likeness to reality. For it to be ascribed face validity, the likeness to reality has to fulfil a relevant, suitable, or useful educational purpose for the learner, and other stakeholders in education. Attitude was defined in this study as "a psychological tendency that is expressed by evaluating a particular entity with some degree of favour or disfavour" (Eagly \& Chaiken, 1993: 1), which means that attitude is not necessarily seen as a predisposition, a long term or enduring state, or as learned behaviour. 


\subsection{Face validity as an affective factor}

Face validity is further identified as an affective factor, perceptions, opinions or attitudes (Chan, 2011: 1; Dudley-Evans \& St. John, 1998: 125 as cited in Rautenbach, 2014: 13; Hutchinson \& Waters, 1987: 166; Sato \& Ikeda, 2015: 2), making it a member of the affective domain, and one of a triad of domains of educational objectives that constitute what is called Bloom's Taxonomy of Educational Objectives. Although initially degraded as inferior to the cognitive and psychomotor domains, the affective domain has had some measure of influence on developments in the conception, implementation, and effectiveness of the curriculum since the 1960s. Subsequently, affective factors, such as needs, wants, motivation, attitudes, and face validity, have become the subjects of many studies. In pursuance of the objectives approach has emerged a new way of curriculummaking that is predicated on identifying the needs of learners as its point of departure, and on accountability to the learners, primarily, for the obligation to meet their needs, as the de facto termination and renewal points in curriculum design. In English Language Teaching (ELT), a movement emerged that claimed to base all of its pedagogic decisions on the needs of learners: English for Specific Purposes, or ESP, for short. In ESP, face validity co-occurs mainly with four other concepts: subject-specificity, authenticity, relevance, and motivation. The theoretical rationale for face validity in ESP is that face validity brings about motivational effects that may have a positive influence on learning performance by the use of highly specialised texts or subject-specific materials, which makes the language seem more relevant, and which, in turn, engenders motivation (Hutchinson \& Waters, 1987: 166). In other words, face validity improves achievement motivation. From this viewpoint, relevance is explained as achievable through the presentation of learning that is meaningful for learners, i.e. learning that caters for the needs of learners in the context of their society. Huckin (2003) also sees face validity as inclusive of subject-specificity, but also suggests awareness or familiarity and knowledge as factors, as evidenced in this expression: "something the student knows that he or she needs to learn" (Huckin, 2003: 5). Fulcher's (1999: 222) explanation of face validity includes authenticity as a requirement for face validity. In turn, he defines authenticity as "the degree to which the outside world is brought into the testing situation" (Fulcher, 1999: 222). The definition of face validity as "perceptions, shaped by prior knowledge and experiences, and how this shapes...wants and needs" is also apparent in Dudley Evans and St. John's (1998: 125 as cited in Rautenbach, 2014: 13) ESP-based interpretation of the concept. From the preceding definitions, it is apparent that face validity in ESP is conceptualised as a function of subject-specificity, relevance, and authenticity, whereas motivation (change in learning behaviour) is presented as the goal or rationale of face validity. 


\subsection{Face validity as a rational goal of course design}

As a course design mechanism, ESP belongs to the class of objects called educational programmes or designs, more specifically, language education programmes. As an educational programme or design, ESP, as do other educational designs, becomes subject to educational theory and practice (the curriculum) regardless of whether validations of these are through nomological networks, the theory-constituting systems of scientific laws proposed by Cronbach and Meel (1955); by the score-based interpretations, arguments and inferences proposed by Messick (1989), and supported by Kane (2001), or by the realist measurementcausal attributions approach of Borsboom, Mellenbergh, and van Heerden (2004, as critically discussed in Baghaei \& Yazdi, 2016: 169-170, and in Colliver, Conlee, \& Verhulst, 2012: 367-369). ESP initially sought to set itself apart from language education theory and practice as a special kind of ELT with special methodologies, but the reality of the practical constraints imposed by non-observance of curriculum principles often inhibited the effectiveness of this language teaching approach, as came to the fore in the shortcomings identified in Munby's needs analysis model of 1978. However, a combination of factors, ranging from the paucity of a strictly syllabus-based design approach to the imposition of centralised curriculum planning in many polities, has resulted in ESP accepting its status as a language education approach, and the primacy of curriculum principles in education programme planning.

Messick (1995: 745) recommends curriculum analysis, and other types of analyses, including domain theory analysis, as tools that could be considered for service in investigating validity evidence. The problem with curriculum analysis, however, is its suggestion of a post hoc or summative understanding of validation. In reality, practitioners develop a curriculum in both its narrow and broad meanings from curriculum principles (values) and evidence (facts), which Hutchinson and Waters (1987: 65) respectively refer to as theoretical rationales and empirical information - the same terminology used by Messick (1989 as cited in Messick, 1998: 3) to define validity. The clearest understanding of the link between curriculum design and courses from the perspective of validity theory is offered by Weidemann (2011: 101), who argues that language tests, courses, and curricula are applied linguistic artefacts or designs that rely on the "technical ability" of the applied linguist for their eventual form. Weidemann argues that language courses are a result of an alignment between the two levels of applied linguistic design, a prior conditioning or norming artefact, and a factual or enduser format of the design. These he restates as normative and factual designs. According to Weidemann (2011: 101), the normative design (technical norms) is the language curriculum, while the factual design (technical facts) is the language course. The theoretical rationales and empirical evidence mentioned by both Messick and Hutchinson and Waters, which Weidemann respectively calls technical norms and technical facts, constitute classes of processes that the 
educational literature has come to identify as curriculum development, or course design. The goal of any curriculum development process is to achieve an attribution of validity, however the concept is defined. This implies that the logical goal of curriculum development or course design processes, whether sequenced linearly or cyclically, is to imbue the course design process itself, and its products, with validity evidence. In fact, to produce valid educational programmes is the goal of educational programme designers, who, armed with beliefs, attitudes, values, and hope, in other words, with a philosophy, attempt to infuse their courses with validity-supportive features or qualities, in order to induce favourable responses from the end-users or consumers of educational designs. Similarly, the end-users, with their attitudes, beliefs, and values, respond in a manner that may suggest that the course designers may have succeeded or failed.

This suggests the need for a curriculum-based (idiographic) concept of validity, which is long overdue, given the impregnability, for teachers (McNamara \& Roever, 1993: 427 as cited in Rambiritch, 2012: 116), of some of the nomothethic validity concepts from psychometrics. Scott, Yeld, and Hendry (2007: 39 as cited in Council on Higher Education [CHE], 2013: 57) allude to this concept in this formulation:

"Whatever the significance of material and affective conditions, the key factors in student success are academic: in essence, formal learning depends on whether students can and do respond positively to the educational process in higher education. The educational process refers not only to 'teaching approaches' but all aspects of the formal system, including the curriculum framework, the design of its component parts, assessment, and student support."

From a broad perspective, therefore, the attitudes, feelings, and opinions, that are said by Nevo (1985) to define face validity, are held about modern curriculum design and educational theory from an educational relevance perspective. This means, for example, that face validity is, basically, student attitudes toward aspects of the following curriculum processes: needs analysis, situational analysis, planning learning outcomes, course organisation, selecting and preparing teaching materials, providing for effective teaching, and evaluation (Richards, 2001: 41). Hargreaves (1989: 36) summarises these processes into designing, implementing, and evaluating - all three of which he characterises as an integral part of curriculum design in an integrated, and cyclical curriculum development system. Nation and Macalister (2010: 134) argue that an evaluation is an essential part of good curriculum design, for making sure that curriculum design weaknesses are found and corrected. Thus, curriculum design, as a whole, is a validating process, in the sense that the course design and implementation aspects of curriculum design could be seen as validity-forming, -infusing, -imbuing, or -supportive processes; in other words, as a validation with the sense "to make valid". On the other hand, the 
evaluation and implementation aspects are also a validation, but with the sense "to confirm the validity of", which suggests that an evaluation is a validity-confirming or -verifying process. Thus, ESP course designers and implementers would use ESP ontologies as the beliefs, values, and attitudes that inform their design and implementation practices, while end-user learners would employ their own beliefs to react or respond to the rationale, form, and delivery of the ESP modules designed for them.

\section{METHODOLOGY}

\subsection{Participants}

This study focussed on a population of first-year Engineering students (about 600) at a campus of a South African university in Gauteng Province, using purposive sampling to extract the biggest possible sample $(\mathrm{N}=226)$ from those taught an ESP module known as "Engineering Communication" (EC). Being ESP practitioners, we took a special interest in Engineering ESP modules, in the hope of adding to the development of this sector after witnessing how particularly difficult it could be to motivate Science, Technology, Engineering, and Maths (STEM) students in ESP modules, and how Engineering practitioners struggled without course books and teaching materials, while their colleagues in Business ESP modules seemed to have sufficient materials. Since ESP modules are, theoretically, meant to be custommade for a particular student, discipline, and juncture, it is imperative to know how ESP practitioners at South African universities have been dealing with this theoretical requirement over the years, especially given the compulsory status of ESP modules. It is equally imperative to know how students respond, not only to the designed product, but also to the underlying assumptions of ESP theory and relevant education.

\begin{tabular}{|c|c|c|c|c|c|c|c|}
\hline \multirow{2}{*}{$\begin{array}{l}\text { Race } \\
(n=224)\end{array}$} & \multicolumn{2}{|c|}{ Black African } & \multicolumn{2}{|c|}{ White } & \multicolumn{3}{|c|}{ Other } \\
\hline & \multicolumn{2}{|l|}{92.0} & \multicolumn{2}{|c|}{5.4} & \multicolumn{3}{|c|}{2.6} \\
\hline \multirow{2}{*}{$\begin{array}{l}\text { Gender } \\
(n=224)\end{array}$} & \multicolumn{3}{|c|}{ Male } & & \multicolumn{3}{|c|}{ Female } \\
\hline & \multicolumn{3}{|c|}{78.6} & \multicolumn{4}{|c|}{21.4} \\
\hline \multirow{2}{*}{$\begin{array}{l}\text { Age Ranges } \\
\text { (in years) }(n=225)\end{array}$} & \multirow{2}{*}{\multicolumn{2}{|c|}{$\begin{array}{l}\leq 19 \\
46.7\end{array}$}} & \multicolumn{2}{|c|}{$20-24$} & \multicolumn{3}{|c|}{$\geq 25$} \\
\hline & & & \multicolumn{2}{|c|}{50.2} & \multicolumn{3}{|c|}{3.1} \\
\hline \multirow{2}{*}{$\begin{array}{l}\text { English Language } \\
\text { Status }(\mathrm{n}=224)\end{array}$} & \multicolumn{2}{|l|}{46.7} & Second Language & \multicolumn{2}{|c|}{ Foreign Language } & \multicolumn{2}{|c|}{ Other } \\
\hline & 6.3 & \multicolumn{2}{|r|}{87.1} & \multicolumn{2}{|c|}{3.1} & \multicolumn{2}{|c|}{3.6} \\
\hline \multirow[t]{2}{*}{$\begin{array}{l}\text { High School Type } \\
(n=224)\end{array}$} & Township School & \multicolumn{2}{|c|}{$\begin{array}{c}\text { Model C } \\
\text { School }\end{array}$} & vate School & \multicolumn{2}{|c|}{$\begin{array}{l}\text { School in } \\
\text { Other Country }\end{array}$} & Other \\
\hline & 59.0 & \multicolumn{2}{|c|}{19.4} & 8.1 & 4 & & 9.5 \\
\hline \multirow[t]{2}{*}{$\begin{array}{l}\text { High School English } \\
\text { Type }(\mathrm{n}=222)\end{array}$} & \multicolumn{2}{|c|}{ English Home Language } & \multicolumn{2}{|c|}{$\begin{array}{c}\text { English First Additional } \\
\text { Language }\end{array}$} & \multicolumn{3}{|c|}{$\begin{array}{c}\text { English Second } \\
\text { Additional Language }\end{array}$} \\
\hline & \multicolumn{2}{|l|}{15.6} & \multicolumn{2}{|c|}{78.1} & \multicolumn{3}{|c|}{6.3} \\
\hline Grade 12 English & \multicolumn{2}{|l|}{ 80-100 } & \multicolumn{2}{|c|}{$60-79$} & & $30-59$ & \\
\hline
\end{tabular}




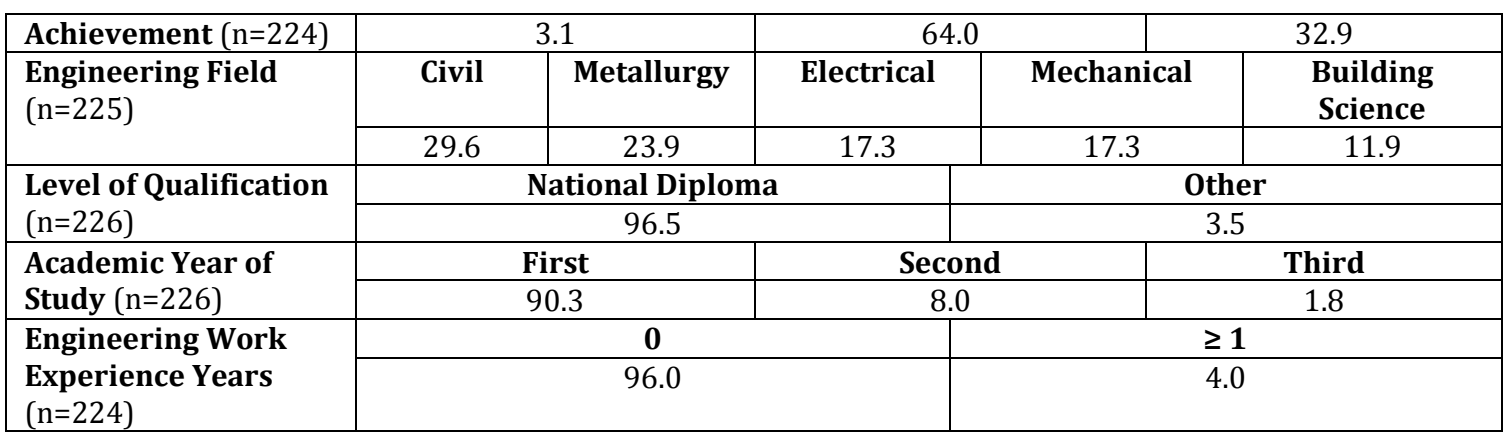

Table 1. Student sample profiles (in \%)

The socio-demographic background of the participants was further defined by means of the eleven attribute variables shown in Table 1 . The other purpose for the inclusion of these socio-demographic variables was to measure their possible influence on the face validity variables by means of statistical significance and measure-of-association tests, the results of which are reported in a separate article. As can be seen on the table, the majority of the Student Respondents (SRs) were ESL speakers (87.1\%), had no engineering work experience $(96 \%)$, were male $(78.6 \%)$, were registered for the National Diploma (96.5\%), and were first year students $(90.3 \%)$.

\subsection{Instruments}

A self-developed questionnaire was the main data collection instrument in this study. It had a biographical section (Section A), an item-ranking section (Section $\mathrm{B}$ ), a 15-item Likert scale (Section C, and the main component of the study), and three 9item Likert-type scales (Sections D, E, and F). A Cronbach reliability test and Exploratory Factor Analysis (Principal Component Analysis [PCA] and Principal Axis Factoring [PAF]) were conducted to test the reliability and construct validity of the Likert scale. The findings of a Cronbach reliability analysis and exploratory factor analysis (EFA) confirmed that the Likert scale had acceptable reliability, as shown by an "acceptable" Cronbach alpha of .671, which improved to .748 with 12 items; and acceptable item discrimination, as signified by two-thirds of the items having corrected item-total correlations of above .200. The EFA and qualitative considerations from the literature review were employed in the grouping of variables into the four factors that the findings below were organised into. Although some of the variables making up the factors did not have inter-correlation, illustrative means of means were calculated to indicate trends within them, and because, qualitatively, the factors were believed to represent the subdimensions of the construct face validity.

The factors are Socio-Industrial Relevance of EC, Curricular Relevance of EC, Motivation to Learn EC, and Desirability of Lecturer Attributes. The bolded words in the long item labels below indicate the shortest names used hereinafter with the 
students' Likert item (SLI) numbers as the substantive item and variable identifiers, in the interest of word economy. The factors of interest were tested by the following SLIs: Socio-industry relevance of Engineering Communication (EC) (three SLIs, and the Content Relevance Index, CRI); Desirability of subject-specific materials (SLI 7); Genderisation or feminisation of English Communication Skills (ECS) (SLI 10); Curricular relevance of EC (six SLIs, and the Content familiarity Index, CFI): Impact of absence of coercion on the choice of EC (SLI 3); Integralness of EC to an Engineering diploma (SLI 4); Characterisation of EC as a nuisance (SLI 5); Competence-induced redundancy of EC (SLI 8); Necessity of management skills (SLI 9); Repetitiveness of EC (SLI 11); Motivation to learn EC (three SLIs, and the Learning Content Enjoyment Index, LCEI): Degree of challenge of ECS (SLI 1); Knowledge of the purpose of EC (SLI 2); Motivation to learn EC (SLI 13); Desirability of lecturer attributes (three SLI variables): Implementation of selfdirected learning (SLI 6); Preference for Engineering qualifications (SLI 12); and Advisability of student agency in EC syllabus design (SLI 14).

Questionnaire data were processed on SPSS, whereby the item means and standard deviations - the main statistics of analysis - were calculated, as were frequency distributions. The Chi Square test was performed to test for independence between the scale items, and the Phi and Cramer's V test to measure the size of statistically significant associations between the items. The confidence level was set at 95\% (0.95), and the confidence interval, at 5\% (0.05). The focus in this paper is, however, on the trends in the item and scale means, and on the merged frequency distributions, which are a more accurate statistic, because of the non-parametric nature of the data. Factor mean of means were calculated, despite the lack of inter-correlation amongst some of the factor variables, as shown in Table 2.

\begin{tabular}{|c|c|c|c|c|}
\hline $\begin{array}{l}\text { ATTITUDINAL } \\
\text { POSITIONS }\end{array}$ & $\begin{array}{c}\text { EVALUATIONS OF } \\
\text { ATTITUDINAL POSITIONS }\end{array}$ & & SCORE UNITS & $\begin{array}{l}\text { UPPER AND LOWER BOUNDS OF } \\
\text { SCORE UNITS }\end{array}$ \\
\hline Strongly agree & Strong positive & \multirow{2}{*}{ 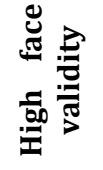 } & 5 & 4.50 to 5.00 \\
\hline Agree & Positive & & 4 & 3.50 to 4.49 \\
\hline Not sure (NS) & Inconclusive negative & \multirow{3}{*}{ 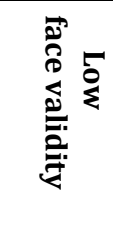 } & 3 & 2.50 to 3.49 \\
\hline Disagree & Negative & & 2 & 1.50 to 2.49 \\
\hline Strongly disagree & Strong negative & & 1 & $1.00-1.49$ \\
\hline
\end{tabular}

Table 2. Likert scale interpretation criteria (adapted from Ditsele, 2014: 146)

The three Likert-type summated scales (applicable to Tables 3, 4, and 5) were interpreted the same as the Likert scale, because of the corresponding scoring and evaluation units between the two scale types, as they were consequently comparable. 
In summary: Very irrelevant/Very boring/Very familiar $(1$ to 1.49); Irrelevant/Boring/Familiar $(1.50$ to 2.49); Not sure (2.50 to 3.49); Relevant/Enjoyable/Unfamiliar (3.50 to 4.49); and Very relevant/Very enjoyable/Very unfamiliar (4.50 to 5.00). The lower end of both scale types (1 to 3.49) represented negative attitudinal positions, and the upper end (3.50 to 5.00), positive attitudinal positions, from the point of view of ESP, and educational relevance principles.

\section{FINDINGS}

Table 3 shows the descriptive statistics for the SLI variables. The bolded items were reverse-coded, while the asterisked ones indicate negative grammatical polarity. The SLIs are presented in descending order from the highest to the lowest mean. ${ }^{1}$

\begin{tabular}{|c|c|c|c|c|c|c|}
\hline STUDENTS' LIKERT ITEMS (SLIS) & MEAN & STD. DEV. & $\begin{array}{c}\text { D } \\
\text { (A) }\end{array}$ & NS & $\begin{array}{c}\text { A } \\
\text { (D) }\end{array}$ & $\mathbf{N}$ \\
\hline $\begin{array}{l}\text { 1. ECS are important in the South African Engineering } \\
\text { industry (SLI 15) }\end{array}$ & 4.33 & .885 & 4.4 & 5.3 & 90.2 & 226 \\
\hline $\begin{array}{l}\text { 2. Engineering students don't need management skills* } \\
\text { (SLI 9) }\end{array}$ & 4.20 & .962 & 6.7 & 12.4 & 80.8 & 225 \\
\hline 3. I know what the purpose of EC is (SLI 2) & 4.18 & 1.205 & 4.0 & 8.00 & 88.0 & 225 \\
\hline $\begin{array}{l}\text { 4. ECS are soft skills more suited to women } \\
\text { (SLI 10) }\end{array}$ & 3.94 & 1.205 & 14.2 & 11.1 & 74.6 & 225 \\
\hline $\begin{array}{l}\text { 5. EC should not be based on topics and materials from } \\
\text { the Engineering field* (SLI 7) }\end{array}$ & 3.91 & 1.131 & 12.5 & 17.4 & 70.1 & 224 \\
\hline $\begin{array}{l}\text { 6. My EC lecturer encourages students to have initiative and } \\
\text { learn on their own (SLI 6) }\end{array}$ & 3.82 & .979 & 11.6 & 12.9 & 75.6 & 225 \\
\hline 7. $\quad$ EC should be part of an Engineering diploma (SLI 4) & 3.69 & 1.164 & 18.8 & 15.6 & 65.6 & 224 \\
\hline $\begin{array}{l}\text { 8. I didn't need EC because my matric English marks } \\
\text { were good* (SLI 8) }\end{array}$ & 3.62 & 1.184 & 20.1 & 12.9 & 67 & 224 \\
\hline $\begin{array}{l}\text { 9. Lecturers should negotiate the content of EC with students } \\
\text { (SLI 14) }\end{array}$ & 3.57 & 1.092 & 17.8 & 21.8 & 60.5 & 225 \\
\hline $\begin{array}{l}\text { 10. Engineering students don't find ECS courses too easy* (SLI } \\
\text { 1) }\end{array}$ & 3.50 & 1.084 & 20.5 & 20.1 & 59.4 & 224 \\
\hline $\begin{array}{l}\text { 11. EC takes up the time I need to study my major courses } \\
\text { (SLI 5) }\end{array}$ & 3.20 & 1.268 & 37.1 & 9.4 & 53.6 & 224 \\
\hline 12. EC is a repetition of high school work (SLI 11) & 3.17 & 1.285 & 38.0 & 12.9 & 49.1 & 224 \\
\hline 13. I always feel so motivated to learn EC (SLI 13) & 3.13 & 1.155 & 32.1 & 21.9 & 46.0 & 224 \\
\hline $\begin{array}{l}\text { 14. I wouldn't have done EC if it was not compulsory* (SLI } \\
\text { 3) }\end{array}$ & 2.86 & 1.363 & 45.1 & 15.2 & 39.7 & 224 \\
\hline \multirow[t]{2}{*}{$\begin{array}{l}\text { 15. EC should be taught by a lecturer with Engineering } \\
\text { qualifications (SLI 12) }\end{array}$} & 2.85 & 1.365 & 43.3 & $\mathbf{1 7 . 0}$ & 39.8 & 224 \\
\hline & 3.6 & 1.088 & 21.7 & 14.3 & 64 & \\
\hline
\end{tabular}

Table 3. Descriptive statistics for SLIs (ordered from highest to lowest mean)

1 Std. dev. stands for "Standard deviation", D for "Disagree”, NS for "Not sure", A for "Agree", and N for "size of valid sample". The one-word short item names employed in the prose below, with the original SLI numbers (in brackets) to refer to the SLI variables, are used in the interest of word economy and facility of discussion. 


\subsection{The face validity ratio}

This ratio refers to the number of scale items indicative of a positive attitudinal tendency versus the number of those that were seen as indicative of the opposite. Two-thirds (or 10) of the SLIs registered means equal to (or above) 3.50, the lower threshold for a positive mean attitudinal position or a high degree of face validity, while a third (or 5), recorded means below 3.49, the upper bound of a negative mean attitudinal position, or a low degree of face validity. The ratio changed to 58 : 42 , but remained in favour of the positive SLI variables upon the discounting of the three SLIs with negative corrected item-total correlations.

\subsection{Face validity factors and variables}

Table 4 contains findings of the Chi Square test of interdependence and strength of association. The strongest associations, all of which involved SLI 8 (Redundancy) have Cramer's V coefficients of .325, .321 .319, and .314 which makes them moderate associations (between .20 and .40) on the basis of the evaluative scale presented in Rea and Parker (1992 as cited in Kotrlik \& Williams, 2003: 5). All the other associations are still moderate (most below .30), weak and negligible (below .20 ) by the same categorisation. SLI 3 (Choice) recorded the most (10) statistically significant intervariate associations, while SLI 1 (Challenge) recorded the least (1).

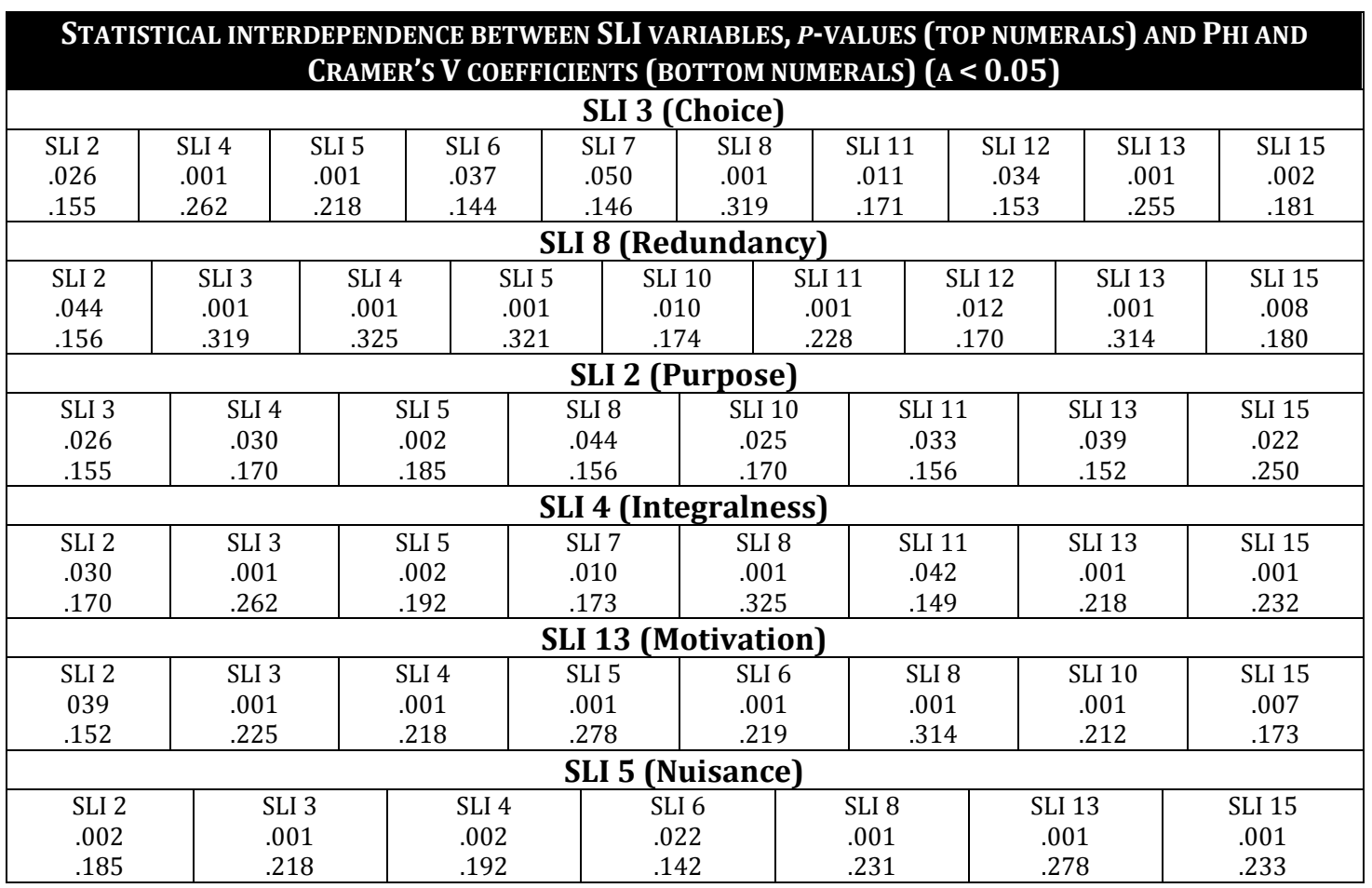




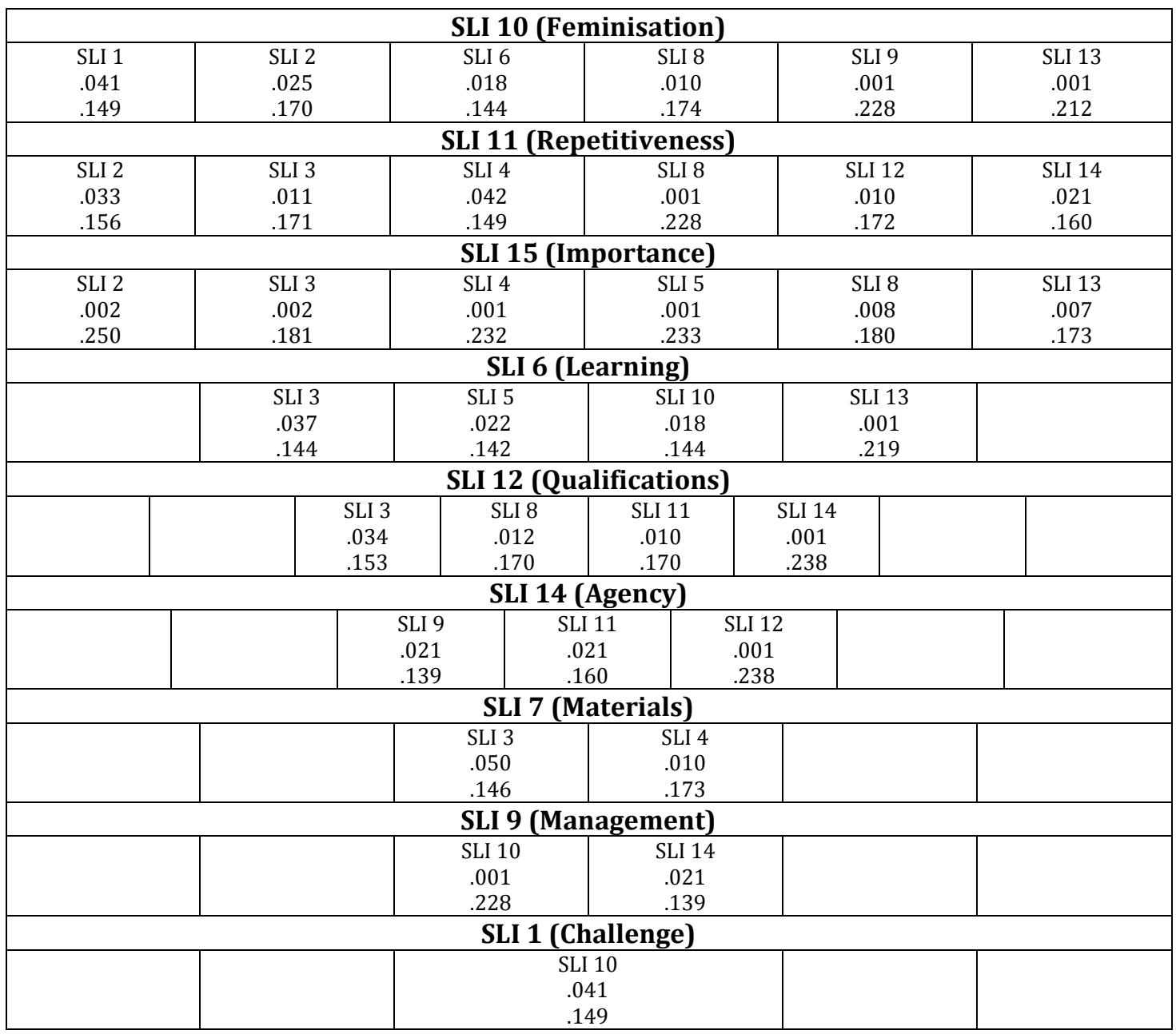

Table 4. Statistical interdependence and strength of association between SLI variables

\subsubsection{The socio-industrial relevance of EC}

Chi Square test findings (in Table 4) revealed that the three SLI variables (SLIs 7, 10 , and 15) constituting this factor were independent of each other. Importance (SLI 15) attained a mean of 4.33, the highest Likert-scale mean, indicating that Student Respondents (SRs) agreed with the statement, an indication of a positive mean attitudinal position, and of the acceptance of the importance of ECS skills to the Engineering industry. As illustrated in Table 5, EC topics scored a mean of means of 4.34 in an Engineering-field-relevance rating test, signifying the positive mean attitudinal position of relevant. 


\begin{tabular}{|l|l|l|}
\hline Rank No. & $\begin{array}{l}\text { Engineering Communication Syllabus Topics } \\
\text { (Original scale number in brackets) }\end{array}$ & Means \\
\hline 1. & Meetings (8) & 4.53 \\
\hline 2. & Report writing (6) & 4.50 \\
\hline 3. & Reading, interpretation and listening skills (1) & 4.44 \\
\hline 4. & Employment processes (7) & 4.44 \\
\hline 5. & Communication products (4) & 4.35 \\
\hline 6. & Communication strategies (3) & 4.34 \\
\hline 7. & Visual elements and presentations (5) & 4.33 \\
\hline 8. & The CMAPP communication model (2) & 4.17 \\
\hline 9. & Ethics and intercultural communication (9) & 4.00 \\
\hline & Mean of means (Content Relevance Index) & $\mathbf{4 . 3 4}$ \\
\hline
\end{tabular}

Table 5. EC syllabus topics (ordered from highest to lowest means)

No syllabus topic means (in Table 5) registered below 4.00, confirming each of their evaluations by the sample as relevant to the Engineering profession. The most relevant topics, by their respective highest means of 4.53 and 4.50, whereby they both actually achieved ratings of very relevant, were meetings and report writing. The lowest scoring items, and by virtue thereof, the least relevant topics, were the CMAPP communication model and ethics and intercultural communication, with respective means of 4.17 and 4.00. Feminisation (SLI 10) scored a mean of 3.94, showing a mean tendency of disagreement with the statement, which was indicative of a positive mean attitudinal position. This suggested a rejection by a SR majority (74.7 percent, to be precise) of the gendered viewpoint that ECS, as "soft skills", were more suited to women. Materials (SLI 7) recorded a mean of 3.91, which denoted general disagreement with the statement, and a positive mean attitudinal position. A clear majority of 70.1 percent of SRs disagreed with the proposition in the statement that EC should not be based on subject-specific or authentic materials.

\subsubsection{The curricular relevance of EC}

The six SLI variables (SLIs 3, 4, 5, 8, 9, and 11) recorded a near acceptable Cronbach's alpha of .695, and were, apart from SLI 9, intercorrelated with each other, suggesting that they could be the construct face validity itself, or a subscale thereof. Chi Square tests were not conducted to test interdependence between CFI syllabus topics and any of the SLIs, for practical reasons.

Management (SLI 9) scored a mean of 4.2, pointing to collective disagreement with the statement, and a positive mean attitude. A majority of 80.9 percent of SRs disagreed with the statement, thereby rejecting the sentiment that Management Skills, which, together with English Communication Skills, is a service subject in the Engineering Faculty, were not needed by engineers. Integralness (SLI 4) recorded a mean of 3.69, signalling agreement with the statement, a positive mean tendency, 
and, thereby, acceptance of the sentiment in the statement that EC was integral to any Engineering diploma. Redundancy (SLI 8) registered a mean of 3.62, which implied disagreement with the statement, suggesting a positive mean attitudinal position. The data showed that a sample majority of 67 percent did not believe that a good Grade 12 examination score exempted them from needing EC. Nuisance (SLI 5) recorded a mean of 3.20, suggesting a tendency towards the inconclusive negative attitudinal position of not sure, further suggesting no rejection of the notion that EC was a nuisance. Repetitiveness (SLI 11) attained a mean of 3.17, a rating of not sure, an inconclusive negative mean attitudinal position, which was indicative of no rejection of the sentiment that EC was a repetition of high school work. Choice (SLI 3) recorded a mean of 2.86, signifying a tendency towards not sure, and an inconclusive negative mean attitudinal position. As shown in Table 6, the CFI registered a mean of means of 2.58 , indicating the inconclusive negative mean attitudinal position of not sure.

\begin{tabular}{|l|l|l|}
\hline RANK No. & ENGINEERING COMMUNICATION SYLLABUS TOPICS & MEANS \\
\hline 1. & The CMAPP communication model (2) & 3.36 \\
\hline 2. & Ethics and intercultural communication (9) & 2.96 \\
\hline 3. & Report writing (6) & 2.85 \\
\hline 4. & Employment processes (7) & 2.72 \\
\hline 5. & Meetings (8) & 2.67 \\
\hline 6. & Communication strategies (3) & 2.56 \\
\hline 7. & Visual elements and presentations (5) & 2.15 \\
\hline 8. & Communication products (4) & 2.08 \\
\hline 9. & Reading, interpretation and listening skills (1) & 1.86 \\
\hline & Mean of means (Content Familiarity Index) & $\mathbf{2 . 5 8}$ \\
\hline
\end{tabular}

Table 6. EC syllabus topics rank-ordered by familiarity

The CMAPP communication model and ethics and intercultural communication attained the highest respective means of 3.36 and 2.96, signifying the mean attitudinal positions of not sure. Three topics registered means below the lower bound of 2.50, which signified the negative mean attitudinal position of familiar, which suggested that SRs might have found the topics to be repetitive of high school syllabus topics.

\subsubsection{Motivation to learn EC}

Table 4 reveals that there was only one weak interdependence relationship (between SLI 2 and SLI 13) between the three SLI variables, which registered a 
mean of means of 3.65. Purpose (SLI 2) registered a mean of 4.18, which indicated a mean tendency to agreement with the statement, and a positive mean attitudinal position. By agreement with the statement, a commanding 88 percent sample majority suggested that they were aware of the purposes of EC. Challenge (SLI 1) attained a mean of 3.50, signifying marginal agreement with the statement, and a positive mean attitudinal position. A sizeable respondent majority of 59.40 percent agreed that they did not believe the perspective that Engineering students, which they were, experienced ECS subjects as unchallenging or boring. Motivation (SLI 13) attained a mean of 3.13, indicating a rating of not sure, and an inconclusive negative mean attitude position. A sample minority of 46 percent agreed that they were always motivated to learn EC. It is illustrated in Table 7 that the rating of topics for enjoyment of learning produced a mean of means of 3.78, and the positive mean attitudinal position of enjoyable.

\begin{tabular}{|l|l|l|}
\hline RANK No. & ENGINEERING COMMUNICATION SYLLABUS TOPICS & MEANS \\
\hline 1. & Meetings (8) & 4.03 \\
\hline 2. & Report writing (6) & 3.91 \\
\hline 3. & Employment processes (7) & 3.91 \\
\hline 4. & Communication strategies (3) & 3.90 \\
\hline 5. & Visual elements and presentations (5) & 3.90 \\
\hline 6. & Communication products (4) & 3.86 \\
\hline 7. & The CMAPP communication model (2) & 3.54 \\
\hline 8. & Ethics and intercultural communication (9) & 3.51 \\
\hline 9. & Reading, interpretation and listening skills (1) & 3.49 \\
\hline & Mean of means (Content Enjoyment Index) & $\mathbf{3 . 7 8}$ \\
\hline
\end{tabular}

Table 7. EC syllabus topics rank-ordered by enjoyableness

Meetings and report-writing recorded the highest means of 4.03 and 3.91, respectively, while reading, interpretation and listening skills and ethics and intercultural communication recorded the lowest means of 3.49 and 3.51, respectively. By registering a mean below 3.50, the lower bound of the enjoyable interval, reading, interpretation and listening skills was the only item to fall below the mean rating of enjoyable to not sure, which represented an inconclusive negative mean attitudinal position for this particular item.

\subsubsection{Desirability of lecturer attributes}

Based on Chi Square findings (Table 4), SLI 12 and SLI 14 were interdependent, whereas SLI 6 was independent of both. Learning (SLI 6) recorded a mean of 3.82, which suggested overall agreement with the statement, pointing to a positive mean attitudinal position. It also implied that SRs (75 percent of them) claimed to have 
observed their lecturers practice what they believed to be self-directed learning. Agency (SLI 14) obtained a mean of 3.57, which was reflective of agreement with the statement, and a positive mean attitudinal position. This implied that a sizeable majority of SRs (59.5 percent) agreed with the sentiment that students should be involved in syllabus design processes as agents-negotiators. Qualifications (SLI 12) attained a mean of 2.85 , pointing to a tendency to not sure, and an inconclusive negative mean attitudinal position. This suggested that the student sample might have believed that an Engineering qualification was desirable for teaching EC.

\section{DISCUSSION}

There was a perceived high degree of socio-industrial relevance for EC, as indicated by a sample mean of means of 4.13 on the three SLIs, and the CRI, known as the face validity variables. Socio-industrial relevance, especially the perception of the relevance of the module to the engineering industry, was expected to determine the module's relevance to the Engineering curriculum. Although English Communication Skills (ECS) modules, in general, have many strengths, their academic status appears to be diminished. Johnson's (2012) study with Japanese first-year Engineering students makes the finding of acceptance of the relevance of ECS modules by Engineering students, even as the students remain disaffected toward them. Morraele and Pearson (2003 as cited in Sulcas \& English, 2010: 219) refer to the many studies conducted in the quest to prove the importance of communication skills to Engineering, which have provided the evidence of the acknowledgement among students, and other important stakeholders, from STEM (Science, Technology, Engineering, and Maths) disciplines, of the importance, value, or relevance of communications skills and knowledge to their field of practice. The rejection of a feminised view of ECS, as signified by a mean of 3.94 on Feminisation (SLI 10), may be an indirect signal of the progress being made against the historical construction of Engineering as a masculine profession, consisting in what is known as "hard skills", whose characterisation has been recognised as the main factor in the underrepresentation of women in STEM disciplines and professions (Phipps, 2002 as cited in Du Toit \& Roodt, 2009: 79), and which negates the social value of gender equality. Instead of a technical distinction, Hong (2016: 3) characterises the division between soft skills and hard skills as a gendered division, whereby "soft skills" is directed into an alignment with femininity, and "hard skills" with masculinity, and then followed by the devaluing of the "feminine skills" by tending to associate them with less prestige, lack of intellectual rigour, and only with the Humanities, as a trope of devalued knowledge. Undoing the diachronic and synchronic effects of sexism and elitism is, as highlighted in the prescribed book by Ingre (2008: 5-6), an important goal in Engineering education and professional practice. As for undoing gender discrimination in Engineering education, the Council on Higher Education (CHE, 
2013: 52) has noted that the higher education system was not meeting the country's needs, in respect of equity and social cohesion. Although they are not technically soft skills, Sulcas and English (2010: 222) report that "effectiveness in communicating ideas" was ranked second only to "problem recognition and solution skills", in curricular importance in a then-recent Engineering task force study. The two authors even describe "written and verbal communication" as a highly rated soft skill, which Moss and Tilly (1996: 258), in contrast, categorise as a hard skill. However, that high rating would not necessarily translate into a high status or prestige, as academic and professional prestige seems to be reserved for the sciences, especially the natural sciences.

A sample mean of means of 3.33 for the six SLIs and the CFI signified a perceived low degree of curricular relevance for EC. This factor, which was plausibly a subscale, because of an almost "acceptable" Cronbach's alpha, and relatively strong intercorrelation among five of the six variables, reflected a general tendency to a low degree of face validity. These results suggest that a module that might be seen as relevant to the target situation might not necessarily be viewed as worthy of inclusion in the relevant learning programmes.

There was a perceived high degree of motivation to learn EC as indicated by a sample mean of means of 3.65, for the three SLIs and the LCEI. However, Student Respondents (SRs) did not score high on Motivation (SLI 13, 3.13), a face validity variable that directly asked them to declare their motivation levels when learning EC. This might suggest that SRs may not have been as motivated as reflected in the factor of three variables, which would be consistent with findings by Johnson (2012) that the perceived relevance of ECS modules does not necessarily result in increased motivation to learn them. Furthermore, the sample mean of 3.50 for Challenge (SLI 1) suggested that the SRs agreed with the statement that Engineering students, in general, did not find ECS courses too easy. The data suggested that some SRs might have found communication skills modules even too difficult. Johnson (2012: 91) found, in a study on Japanese Engineering students, that one of the reasons these students were not motivated to learn the English module could have been their perception of it as too difficult for them; in other words, their perceived lack of self-efficacy for it. Johnson's conclusion has resonance with Self-Determination Theory (Ryan \& Deci, 2000: 64), which posits that perceived competence, or self-efficacy, is a catalyst for effectance motivation, the type of motivation that one gets from completing a task successfully, competently, and autonomously. This implies that, if learners have a history of struggling with English as a high school subject, they could transfer the anxiety, and lack of expectancy, to university, which could influence them into thinking that the subject is probably beyond their intellectual reach.

A sample mean of means of 3.41 on the three constitutive SLIs signified a perceived low degree of desirability of lecturer attributes even though SRs agreed that their lecturer practised the autonomy-promoting self-directed learning (SLI 6). Otherwise, SRs produced an inconclusive negative finding on the desirability of 
Engineering qualifications for the task of teaching EC, as reflected in the lowest scale mean of 2.85 on Qualifications (SLI 12). This item was reverse-coded to produce a high score for disagreement with the statement, since, from an ESP perspective, ELT qualifications are preferred to Engineering qualifications, particularly by English Departments, and university and Faculty administrations, even though, from a holistic point of view, as Ahmadi (2008) reports, ESP teacher preferences are influenced by membership of a department. That is to say, heads of language departments prefer language-trained ESP professionals, while heads of specialist departments prefer ESP teachers trained in the specialist discipline. Ahmadi (2008) notes, however, that the most important rating, that of ESP learners, favoured an ESP teacher with a language training background. By scoring a sample mean in the inconclusive negative level, the SRs showed that they might have had a preference for a lecturer with Engineering qualifications.

\section{CONCLUSIONS}

The degree of face validity attributed to "Engineering Communication" (EC) was calculated by averaging over four the mean of means for Sections C, D, E, and F of the questionnaire. The averaging, with the 12 -item mean, produced a mean of means of 3.57, and 3.58, with the 15-item mean, which meant that, either way, we failed to reject the Null Hypothesis, which, in turn, suggested that was probably evidence to support the Alternative Hypothesis. That meant that the Student Respondents (SRs) attributed a marginal high degree of face validity to EC, since the mean of means in either case was 3.50 (or above). However, while slightly less than two-thirds (64 percent) of the sample ascribed a high degree of face validity to EC, slightly more than a third (36 percent) remained disaffected.

A high degree of face validity is a strength for any module, as it is desirable, while a low degree of face validity is a threat, since it is undesirable. The following face validity variables, with means below 3.50, represented low face validity threats to the module EC: Nuisance (SLI 5, 3.20); Repetitiveness (SLI 11, 3.17); Motivation (SLI 13, 3.13); Choice (SLI 3, 2.86); Qualifications (SLI 12, 2.85), and the students' Content Familiarity Index (2.58). Three of these variables (SLIs 3, 5, and 13) had high inter-correlations (above .400) with the scale total, the face validity measure. Therefore, whereas the outcome was a high degree of face validity for the sample, the high inter-correlation between the face validity measure and at least three items representing a face validity threat in the Item-Total statistics, and the marginal nature of the mean of means (3.57 or 3.58), suggested that there were threats to this face validity.

The low score on the direct measure of motivation, Motivation (SLI 13), and its inter-correlation with the face validity measure, confirmed (although not in a causal manner) the link theorised in ESP between motivation and face validity. In spite of the endorsement of the socio-industrial relevance of EC, the SRs did not 
reject the notion that EC was a nuisance (SLI 5), and conceded that they would not have done EC, if not coerced by state regulation (SLI 3). Perhaps, for the moment, regardless of how valid or relevant they may be, Humanities disciplines, especially those wrongly or rightly referred to as soft skills, will, for lacking the prestige or status of superiority associated with scientific knowledge, always be seen as unworthy of inclusion in STEM-related learning programmes. The inference that could be drawn was that relevance did not necessarily conduce to motivation and academic worthiness.

The rejection of the feminised statement on ECS could be regarded as signifying the beginning or continuation of the de-gendering of soft skills, and ECS by exemplification (if ECS are soft skills), which would be a social justice necessity, as the de-genderisation of the Engineering profession has been identified as one of the factors that would contribute to increasing the participation rates of women in Engineering, and in STEM disciplines, in general. The positive attitudes of the male sub-group, as shown by positive responses to SLI 10, suggest the probable degenderisation of ECS modules and the Engineering profession.

[Paper submitted 3 Aug 2018]

[Revised version received 11 Nov 2018]

[Revised version accepted for publication 30 Nov 2018]

\section{Acknowledgement}

We would like to express our appreciation to the Department of Applied Languages for according Joseph Moyo study leave to complete his doctoral research project, to the Faculty of Engineering, for their co-operation and assistance, and to Tshwane University of Technology, for their support throughout this study.

\section{References}

Ahmadi, M. (2008). Who should teach ESP: EFL teachers or subject-specialist teachers? TESOL France Journal, 1, 21-33. Retrieved from http://www.tesol france.org/uploaded_files/files/Coll08-Ahmadi.pdf

Anastasi, A. (1988). Psychological testing. New York: Macmillan.

Baghaei, P., \& Yazdi, M. T. (2016). The logic of latent variable analysis as validity evidence in psychological measurement. The Open Psychology Journal, 9, 168-175. doi: $10.2174 / 1874350101609010168$

Barnard, R., \& Zemach, D. (2003). Materials for specific purposes. In B. Tomlinson (Ed.), Developing materials for language teaching (pp. 306-323). London: Continuum.

Borsboom, D. Mellenbergh, G. J., \& van Heerden, J. (2004). The concept of validity. Psychological Review, 111(4), 1061-1071. doi: 10.1037/0033-295X.111.4.1061 
Chan, S. H. C. (2011). Demonstrating cognitive validity and face validity of PTE academic writing items Summarize written text and Write essay. UK: Pearson. Retrieved from https://s3.amazonaws.com/files.formstack.com/uploads/1801396/26959953/18296185 8/26959953_demonstratingcognitiveandfacevalidityofpteacademicwritingitems_2011.pdf

Colliver J. A., Conlee, M. J., \& Verhulst, S. J. (2012). From test validity to construct validity ... and back? Medical Education, 46, 366-371. doi:10.1111/j.1365-2923.2011.04194.x

Cronbach, L. J., \& Meel, P. E. (1955). Construct validity in psychological tests. Psychological Bulletin, 52(4), 281-302. Retrieved from https://marces.org/EDMS623/Cronbach\%20LJ\%20\&\%20Meehl\%20PE\%20(1955) \%20Construct\%20validity\%20in\%20psychological\%20tests.pdf

Council on Higher Education (CHE). (2013). A proposal for undergraduate curriculum reform in South Africa: The case for a flexible curriculum structure. Discussion document. Pretoria: CHE. Retrieved from http://www.che.ac.za/sites/default/files/publications/Full_Report.pdf

Ditsele, T. (2014). Perceptions of black South African languages: A survey of the attitudes of Setswana-speaking university students toward their first language (Unpublished doctoral dissertation). Tshwane University of Technology, Pretoria, South Africa.

Du Toit, R., \& Roodt, J. (2009). Engineers in a developing country: The profession and education of engineering professionals in South Africa. Cape Town: Human Sciences Research Council. Retrieved from http://www.hsrc.ac.za/en/research-outputs/view/4237

Eagly, A. H., \& Chaiken, S. (1993). The psychology of attitudes. Fort Worth, TX: Harcourt Brace Jovanovich.

Evans, M. (1995). Underachievement at South African universities. Studies in Applied Linguistics and Literary Theory, 4(1), 51-79.

Fulcher, G. (1999). Assessment in English for academic purposes: Putting content validity in its place. Applied Linguistics, 20(2), 221-236. Retrieved from http://languagetesting.info/articles/store/FulcherEAP.pdf

Hargreaves, P. (1989). DES-IMPL-EVALU-IGN: An evaluator's checklist. In R. K. Johnson (Ed.), The second language curriculum (pp. 35-47). Cambridge: Cambridge University Press.

Hong, R. (2016). Soft skills and hard numbers: Gender discourse in human resources. Big Data and Society, 3(2), 1-13. doi: 10.1177/2053951716674237

Huckin, T. N. (2003). Specificity in LSP. Iberica, 5, 3-17. Retrieved from http://www.aelfe.org/documents/text5-Huckin.pdf

Hutchinson, T., \& Waters, A. (1987). English for specific purposes: A learning-centred approach. Cambridge: Cambridge University Press.

Ingre, D. (2008). Engineering communication: A practical guide to workplace communications for engineers. International Student Edition. Toronto: Thomson.

Johnson, M. P. (2012). Examining EFL motivation in Japanese engineering students. The Asian ESP Journal, 8(2), 79-102. Retrieved from http://asian-esp-journal.com/wpcontent/uploads/2013/11/Volume-8-2.pdf

Kane, M. T. (2001). Current concerns in validity theory. Journal of Educational Measurement, 38(4), 319-342. Retrieved from https://onlinelibrary.wiley.com/doi/epdf/10.1111/j.1745-3984.2001.tb01130.x

Kilfoil, W. (1998). Reading outcomes in English for academic purposes. Southern African Journal of Applied Language Studies, 6(2), 46-55. 
Kotrlik, J. W., \& Wiliams, H. (2003). The incorporation of strength of association in information technology, learning, and performance research. Information Technology, Learning, and Performance Journal, 21(1), 1-7. Retrieved from https://pdfs.semanticscholar.org/e5c3/504ca4baef11c1cda8ec085833dbccb63259.pdf

Messick, S. (1995). Validity of psychological assessment: Validation of inferences from persons' responses and performances as scientific inquiry into score meaning. American Psychologist, 50(9), 741-749. Retrieved from http://people.tamu.edu/ warthur/611/Journals/Messick\%20\%281995\%29\%20AP.pdf

Messick, S. (1998). Consequences of test interpretation and use: The fusion of validity and values in psychological assessment (RR-98-48). Princeton, New Jersey: Educational Testing Service. Retrieved from http://www.ets.org/Media/Research/pdf/RR-98-48.pdf

Moss, P., \& Tilly, C. (1996). "Soft" skills and race: An investigation of black men's employment problems. Work and Occupations, 23(3), 252-276. Retrieved from https://www.researchgate.net/publication/258200273_Soft_Skills_and_Race_An_In vestigation_of_Black_Men's_Employment_Problems

Munby, J. (1978). Communicative syllabus design. Cambridge: Cambridge University Press.

Nation, I. S. P., \& Macalister, J. (2010). Language curriculum design. New York \& London: Routledge.

Nevo, B. (1985). Face validity revisited. Journal of Educational Measurement, 22(4), 287-293. Retrieved from https://www.jstor.org/stable/1434704?seq=1\#page_scan_tab_contents

Rambiritch, A. (2012). Challenging Messick: Proposing a theoretical framework for understanding fundamental concepts in language testing. Journal for Language Teaching, 46(2), 108-121.

Rautenbach, E. (2014). Developing curricula for English for occupational purposes: A case study at a university of technology (Unpublished doctoral dissertation). Tshwane University of Technology, Pretoria, South Africa.

Richards, J. C. (2001). Curriculum development in language teaching. Cambridge: Cambridge University Press.

Ryan, R. M., \& Deci, E. L. (2000). Intrinsic and extrinsic motivations: Classic definitions and new directions. Contemporary Educational Psychology, 25(1), 54-67. https://doi.org/10.1006/ceps.1999.1020

Sato, T., \& Ikeda, N. (2015). Test-taker perception of what test items measure: A potential impact of face validity on student learning. Language Testing in Asia, 5(10), 1-16. https://doi.org/10.1186/s40468-015-0019-z

Sulcas, G., \& English, J. (2010). A case for focus on professional communication skills at senior undergraduate level in engineering and the built environment. Southern African Linguistics and Applied Language Studies, 28(3), 219-226. Retrieved from http://dx.doi.org/10.2989/16073614.2010.545024

Vongo, M. R. (2005). A case study of the goals of the business communication course at Technikon Witwatersrand (Unpublished MA thesis). Rhodes University, Grahamstown, South Africa.

Weidemann, A. (2011). Academic literacy tests: Design, development, piloting and refinement. Journal for Language Teaching, 45(2), 100-113. 
JOSEPH MOYO is a Lecturer in the Department of Applied Languages, Tshwane University of Technology, Pretoria, South Africa. His areas of specialisation are TESOL and ESP.

CHARLES C. MANN is a Research Professor in the Department of Applied Languages, Tshwane University of Technology, Soshanguve South, South Africa. His areas of specialisation are Sociolinguistics, Contact Linguistics, Language Attitudes, Language Policy and Planning, and TESOL.

\title{
Appendix
}

\section{Engineering students' questionnaire}

\begin{abstract}
Thank you for taking the time to complete this survey questionnaire. This survey provides you with an opportunity to share your thoughts on English communication skills in the Engineering field, in general, and on the Engineering Communication course you just completed, specifically. Your responses will therefore provide important information that will help English communication skills practitioners and academic institutions know what you think of English communication skills in your field when they plan and/or revise the curriculum. The results of this survey will be published as part of a doctoral thesis. Please understand that the information you provide in this questionnaire will be treated completely confidentially and anonymously, and so will be used only for research purposes. Kindly answer the questions as completely and honestly as possible.
\end{abstract}

\section{SECTION A: BIOGRAPHICAL AND STATUS DATA}

1. Are you male or female?

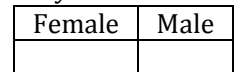

2. How old are you?

\begin{tabular}{|c|c|c|c|c|}
\hline 19 or younger & $20-24$ years & $25-30$ years & $31-34$ years & 35 or more \\
\hline & & & & \\
\hline
\end{tabular}

3. How would you describe yourself?

\begin{tabular}{|l|l|l|l|l|}
\hline African & Coloured & Indian & White & Other \\
\hline & & & & \\
\hline
\end{tabular}

4. Is English your mother tongue/home/second/third/foreign language?

\begin{tabular}{|c|c|c|c|c|}
\hline $\begin{array}{c}\text { Mother } \\
\text { Tongue }\end{array}$ & $\begin{array}{c}\text { Home } \\
\text { Language }\end{array}$ & $\begin{array}{c}\text { Second } \\
\text { Language }\end{array}$ & $\begin{array}{c}\text { Third } \\
\text { Language }\end{array}$ & $\begin{array}{c}\text { Foreign } \\
\text { Language }\end{array}$ \\
\hline & & & & \\
\hline
\end{tabular}

5. What type of secondary/high school did you attend?

\begin{tabular}{|c|c|c|c|c|}
\hline $\begin{array}{c}\text { Former } \\
\text { Model C }\end{array}$ & $\begin{array}{c}\text { Private } \\
\text { School }\end{array}$ & $\begin{array}{c}\text { Township } \\
\text { School }\end{array}$ & $\begin{array}{c}\text { School in } \\
\text { another country }\end{array}$ & Other \\
\hline & & & & \\
\hline
\end{tabular}

6. What English did you do in high school?

\begin{tabular}{|c|c|c|}
\hline $\begin{array}{c}\text { Home Language } \\
\text { OR Mother Tongue }\end{array}$ & $\begin{array}{c}\text { First Additional } \\
\text { OR Second Language }\end{array}$ & $\begin{array}{c}\text { Second Additional } \\
\text { OR Third Language }\end{array}$ \\
\hline & & \\
\hline
\end{tabular}

7. What final score did you achieve for your Grade 12/matric English?

\begin{tabular}{|l|l|l|l|l|}
\hline $0-29 \%$ & $30-39 \%$ & $40-59 \%$ & $60-79 \%$ & $80-100 \%$ \\
\hline & & & & \\
\hline
\end{tabular}

8. What field of Engineering are you studying?

\begin{tabular}{|c|c|c|c|l|l|l|l|}
\hline Chem & Civil & Electrical & Geomatics & Industrial & Mechanical & Mechatronics & Metallurgy \\
\hline & & & & & & & \\
\hline
\end{tabular}


9. What qualification are you now studying towards?

\begin{tabular}{|l|l|l|l|}
\hline Certificate & N Diploma & B Tech & M Tech \\
\hline & & & \\
\hline
\end{tabular}

10. What academic year of study are you in?

\begin{tabular}{|c|c|c|c|}
\hline First & Second & Third & Fourth \\
\hline & & & \\
\hline
\end{tabular}

11. How many years of work experience do you have in Engineering?

\begin{tabular}{|c|c|c|c|c|}
\hline 0 years & $1-5$ years & $6-10$ years & $11-15$ years & 16 or more \\
\hline & & & & \\
\hline
\end{tabular}

\section{SECTION B}

Rank each of these subjects in terms of their importance to the Engineering profession, with 1 being the most important and 4 being the least important.

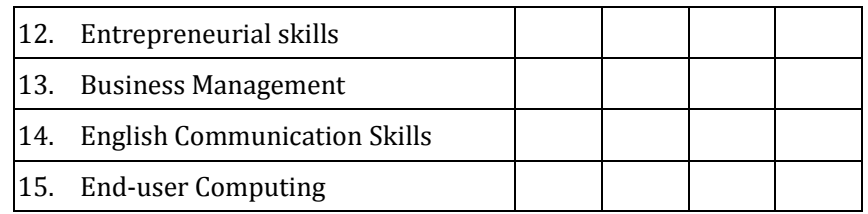

\section{SECTION C}

How do you feel about each of the following statements?

\begin{tabular}{|c|c|c|c|c|c|}
\hline & $\begin{array}{l}\text { Strongly } \\
\text { disagree }\end{array}$ & Disagree & Not sure & Agree & $\begin{array}{l}\text { Strongly } \\
\text { agree }\end{array}$ \\
\hline $\begin{array}{l}\text { 1. Engineering students don't find English communication } \\
\text { skills courses too easy }\end{array}$ & & & & & \\
\hline 2. I know what the purpose of Engineering Communication is & & & & & \\
\hline $\begin{array}{l}\text { 3. I wouldn't have done Engineering Communication if it } \\
\text { was not compulsory }\end{array}$ & & & & & \\
\hline $\begin{array}{ll}\text { 4. Engineering Communication should be part of an } \\
\text { Engineering diploma }\end{array}$ & & & & & \\
\hline $\begin{array}{l}\text { 5. Engineering Communication takes up the time I need to } \\
\text { study my major courses }\end{array}$ & & & & & \\
\hline $\begin{array}{l}\text { 6. My Engineering Communication lecturer encourages } \\
\text { students to have initiative and learn on their own }\end{array}$ & & & & & \\
\hline $\begin{array}{l}\text { 7. Engineering Communication should not be based on } \\
\text { topics and materials from the Engineering field }\end{array}$ & & & & & \\
\hline $\begin{array}{l}\text { 8. I didn't need Engineering Communication because my } \\
\text { matric English marks were good }\end{array}$ & & & & & \\
\hline 9. Engineering students don't need management skills & & & & & \\
\hline $\begin{array}{l}\text { 10. English communication skills are soft skills more suited } \\
\text { to women }\end{array}$ & & & & & \\
\hline $\begin{array}{l}\text { 11. Engineering Communication is a repetition of high } \\
\text { school work }\end{array}$ & & & & & \\
\hline $\begin{array}{l}\text { 12. Engineering Communication should be taught by a } \\
\text { lecturer with engineering qualifications }\end{array}$ & & & & & \\
\hline $\begin{array}{l}\text { 13. I always feel so motivated to learn Engineering } \\
\text { Communication }\end{array}$ & & & & & \\
\hline $\begin{array}{l}\text { 14. Lecturers should negotiate the contents of Engineering } \\
\text { Communication with students }\end{array}$ & & & & & \\
\hline $\begin{array}{l}\text { 15. English communication skills are important in the South } \\
\text { African Engineering industry }\end{array}$ & & & & & \\
\hline
\end{tabular}




\section{SECTION D: CONTENT RELEVANCE}

How irrelevant or relevant are each of these Engineering Communication topics to the Engineering profession?

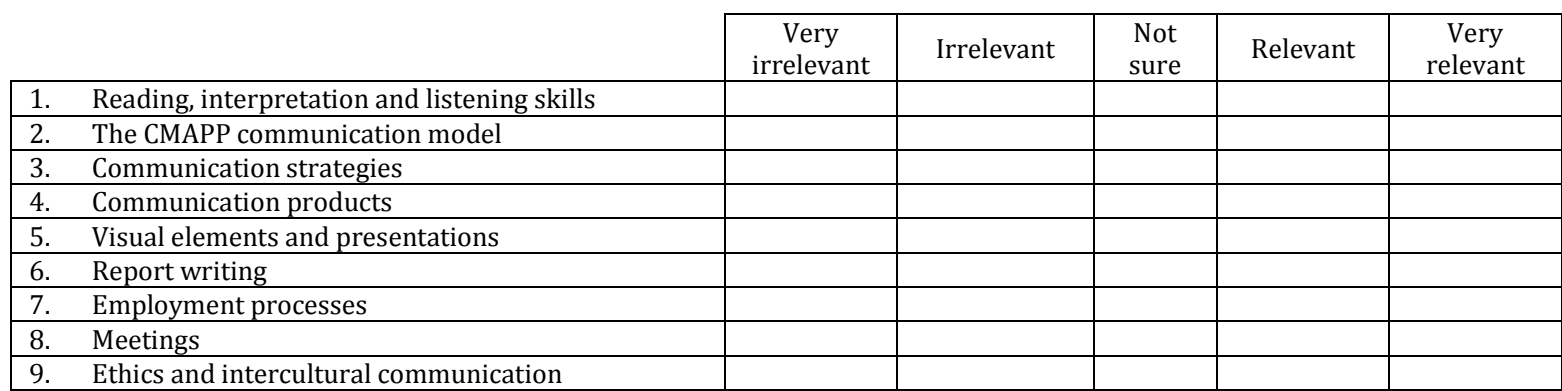

\section{SECTION E: LEARNING ENJOYMENT INDEX}

How did you find learning each of these Engineering Communication topics?

\begin{tabular}{|c|c|c|c|c|c|c|}
\hline & & $\begin{array}{c}\text { Very } \\
\text { boring }\end{array}$ & Boring & Not sure & Enjoyable & $\begin{array}{c}\text { Very } \\
\text { enjoyable }\end{array}$ \\
\hline 1. & Reading, interpretation and listening skills & & & & & \\
\hline 2. & The CMAPP communication model & & & & & \\
\hline 3. & Communication strategies & & & & & \\
\hline 4. & Communication products & & & & & \\
\hline 5. & Visual elements and presentations & & & & & \\
\hline 6. & Report writing & & & & & \\
\hline 7. & Employment processes & & & & & \\
\hline 8. & Meetings & & & & & \\
\hline & Ethics and intercultural communication & & & & & \\
\hline
\end{tabular}

\section{SECTION F: CONTENT FAMILIARITY}

How did you find each of these Engineering Communication topics when they were introduced and taught to you?

\begin{tabular}{|c|c|c|c|c|c|c|}
\hline & & $\begin{array}{c}\text { Very } \\
\text { unfamiliar }\end{array}$ & Unfamiliar & $\begin{array}{l}\text { Not } \\
\text { sure }\end{array}$ & Familiar & $\begin{array}{c}\text { Very } \\
\text { familiar }\end{array}$ \\
\hline 1. & Reading, interpretation and listening skills & & & & & \\
\hline 2. & The CMAPP communication model & & & & & \\
\hline 3. & Communication strategies & & & & & \\
\hline 4. & Communication products & & & & & \\
\hline 5. & Visual elements and presentations & & & & & \\
\hline 6. & Report writing & & & & & \\
\hline 7. & Employment processes & & & & & \\
\hline 8. & Meetings & & & & & \\
\hline & Ethics and intercultural communication & & & & & \\
\hline
\end{tabular}

